\title{
PERLINDUNGAN HUKUM TERHADAP KONSUMEN PENGOBATAN TERAPI BEKAM DI WILAYAH BOGOR
}

\section{LEGAL PROTECTION OF CONSUMERS FROM CUPPING THERAPY METHOD IN BOGOR AREA}

Budi Santoso

Magister Hukum Sekolah Pascasarjana,

Universitas Djuanda Bogor.

Korespondensi : Budi Santoso, Telp.

e-mail : budi.santosoo21@unida.ac.id

Jurnal Living Law, Vol. 13, No. 1 ,

2021

hlm. 72-83

\begin{abstract}
The objectives of this study are: 1) To determine and analyze the legal protection of consumers from traditional medicine with the method of cupping treatment in the Regency and City of Bogor. 2) To find out and analyze the responsibilities of cupping treatment businesses in Bogor Regency and City towards consumers who have suffered losses. The research method used in this study is a normative juridical research that uses a qualitative approach. The results of this study are: 1) Protection of cupping treatment consumers in Bogor Regency and Bogor City, in dispute resolution can be done through a mechanism that has been regulated in the Consumer Protection Law, namely through a dispute resolution mechanism in court or outside the court. 2) The responsibility of the cupping treatment business actors to consumers who are harmed can be accountable for their actions both civil and criminal. This is aimed at increasing the bargaining position of consumers in making transactions with business actors, so that they are not treated arbitrarily because there is a law that regulates it.
\end{abstract}

Keywords: Legal Protection; Consumer; Traditional Treatment.

\begin{abstract}
Abstrak : Tujuan penelitian ini yaitu: 1) Untuk mengetahui dan menganalisis perlindungan hukum terhadap konsumen dari pengobatan tradisional dengan metode pengobatan bekam di Kabupaten dan Kota Bogor. 2) Untuk mengetahui dan menganalisis tanggung jawab pelaku usaha pengobatan bekam di Kabupaten dan Kota Bogor terhadap konsumen yang dirugikan. Metode penelitian yang digunakan dalam penelitian ini adalah penelitian yuridis normatif yang melakukan pendekatan kualitatif. Hasil dari penelitian ini yaitu: 1) Perlindungan terhadap konsumen pengobatan bekam di Kabupaten Bogor dan Kota Bogor, dalam penyelesaian sengketa dapat dilakukan melalui mekanisme yang telah diatur dalam Undangundang Perlindungan Konsumen, yakni melalui mekanisme penyelesaian sengketa di dalam pengadilan atau di luar pengadilan. 2) Tanggung jawab pelaku usaha pengobatan bekam terhadap konsumen yang dirugikan dapat mempertanggungjawabkan tindakannya secara perdata maupun pidana. Hal ini ditujukan untuk meningkatkan posisi tawar konsumen dalam bertransaksi dengan pelaku usaha, sehingga tidak diperlakukan sewenang-wenang karena telah ada undang-undang yang mengaturnya.
\end{abstract}

Kata Kunci: Perlindungan Hukum; Konsumen; Pengobatan Tradisional.

\section{PENDAHULUAN}

Pelaksanaan pembangunan nasional berakibat pada berbagai segi kehidupan berbangsa dan bernegara, terutama berpengaruh pada kehidupan sosial. Sebagaimana telah diamanatkan dalam Alinea Keempat Pembukaan Undangundang Dasar Negara Republik Indonesia Tahun 1945 (UUD RI Tahun 1945) bahwa 
negara bertujuan mewujudkan keadilan sosial dan kesejahteraan umum bagi seluruh rakyat Indonesia. ${ }^{1}$

Kesehatan adalah kebutuhan setiap manusia yang harus dipenuhi. Sebagaimana dimaksud dalam Pancasila dan UUD RI Tahun 1945, bahwa kesehatan merupakan hak asasi manusia, salah satu unsur kesejahteraan yang harus diwujudkan sesuai dengan cita-cita bangsa Indonesia. Meskipun sama fundamentalnya dengan hak-hak yang lain, hak atas pelayanan kesehatan sering dianggap lebih mendasar. ${ }^{2}$ Oleh karena itu, hak atas pelayanan kesehatan merupakan suatu hal yang harus dimiliki oleh setiap warga negara Indonesia. Sehingga tidak ada masyarakat yang tidak bisa melakukan pengobatan.

Pengobatan yang dapat dilakukan oleh masyarakat dapat berupa bantuan medis ataupun pengobatan secara tradisional. Meskipun memiliki metode pengobatan yang berbeda, keduanya memiliki tujuan yang sama yaitu untuk memberikan pelayanan kesehatan terbaik bagi seorang pasien.

Pengobatan tradisional pada awalnya telah dikenal oleh masyarakat Indonesia sejak munculnya pemahaman pengobatan yang bersifat mistik dan kepercayaan pada tenaga gaib yang berakar pada animisme. Pada perkembangannya, pengobatan tradisional di Indonesia banyak dipengaruhi oleh budaya asing, seperti India, Cina, Timur Tengah (Arab) dan Eropa. $^{3}$

Seiring dengan berjalannya waktu, semakin banyak usaha dalam bidang pelayanan kesehatan tradisional di Indonesia. Umumnya, pengobatan

1 Endeh Suhartini, Ujang Bahar, Dani Purwanto, Optimalisasi Perlindungan Hukum Tenaga Kerja Dalam Aspek Keselamatan Kerja Pada Proyek Konstruksi di Wilayah Bogor, Jurnal Ilmiah Living Law, Volume 12 Nomor 1, Januari 2020, Hlm. 42.

2 Ari Yunanto, Hukum Pidana Malpraktik Medik (Tinjauan dan Perspektif Medikolegal, Yogyakarta: Penerbit Andi, 2010, Hlm. 19.

3 Cecep Triwibowo, Etika \& Hukum Kesehatan, Yogyakarta: Medical Book, 2014, HIm. 137. tradisional menawarkan harga yang lebih terjangkau dibandingkan dengan pengobatan komplementer dan integrasi. Dengan semakin meningkatnya biaya pengobatan kesehatan, masyarakat banyak beralih kepada pelayanan pengobatan tradisional.

Sejak Tahun 2009, pelayanan kesehatan tradisional diatur dalam tataran undang-undang, yakni Undang-undang No 36 Tahun 2009 tentang Kesehatan. Pasal 1 angka 16 Undang-undang No 36 Tahun 2009 tentang Kesehatan menentukan bahwa pelayanan kesehatan tradisional adalah pengobatan dan/atau perawatan dengan cara dan obat yang mengacu pada pengalaman dan keterampilan turuntemurun secara empiris yang dapat dipertanggungjawabkan dan diterapkan sesuai dengan norma yang berlaku di masyarakat.

Berdasarkan ketentuan tersebut, bisa dijabarkan bahwa pengertian pelayanan kesehatan tradisional mengandung persyaratan:

1. Adanya aktifitas pengobatan dan atau perawatan,

2. Menggunakan cara atau obat tradisional,

3. Berdasarkan pengalaman dan keterampilan turun-temurun,

4. Dapat dipertanggungjawabkan secara empiris, dan

5. Penerapannya sesuai dengan norma yang berlaku di masyarakat.

Adapun tujuan dari keputusan menteri kesehatan tersebut adalah sebagai upaya untuk membina pengobatan tradisional, memberikan perlindungan kepada masyarakat, menginventarisasikan jumlah pengobatan tradisional, serta jenis dan cara pengobatannya.

Meningkatnya pemanfaatan layanan kesehatan tradisional tentu saja perlu dibarengi dengan kajian penguatan hukum terhadapnya. Perannya sebagai salah satu tenaga kesehatan masyarakat perlu didorong dan dijamin secara legal. Selain isu keamanan dan keselamatan konsumen, seorang pengobat tradisional perlu 
mendapatkan perlindungan hukum terhadap profesinya. ${ }^{4}$

Negara menjamin setiap bentuk penyelenggaraan upaya kesehatan dalam rangka peningkatan derajat kesehatan bagi rakyatnya yang diatur dalam Undangundang No. 36 Tahun 2009 tentang Kesehatan. Salah satu bentuk penyelenggaraan upaya kesehatan yang diatur dalam Undang-undang Kesehatan tersebut adalah pengobatan tradisional ${ }^{5}$. Pengobatan tradisional mengacu kepada pengalaman, keterampilan turun-temurun, dan/atau pendidikan/pelatihan, dan ditetapkan sesuai dengan norma yang berlaku dalam masyarakat ${ }^{6}$.

Pengobatan tradisional merupakan salah satu upaya pengobatan dan/atau perawatan cara lain di luar ilmu kedokteran dan/atau ilmu ke perawatan yang banyak dimanfaatkan oleh masyarakat dalam mengatasi masalah kesehatan. Terdapat berbagai jenis pengobatan tradisional, yang didasarkan pada penggunaan tanaman, hewan dan mineral, selain itu juga terdapat terapi dengan cara spiritual dan manual. Dalam aplikasinya, dapat berdiri sendiri atau kombinasi. Masyarakat diberi kesempatan yang seluas-seluasnya untuk mengembangkan, meningkatkan, dan menggunakan pelayanan kesehatan tradisional yang bisa dipertanggungjawabkan manfaat dan keamananannya. ${ }^{7}$

Berbagai pengobatan alternatif begitu menjamur tengah-tengah masyarakat. Bisa dikatakan pengobatan alternatif mampu menjadi pesaing dan penyeimbang pengobatan konvensional. Hal ini

4 Frangkiano B Randang, Model Perlindungan Hukum Bagi Pelaku Pengobatan Tradisional, Manado: Universitas Sam Ratulangi, Jurnal Lex Privatum Vol. V/No. 2/Mar-Apr/2017, Hlm. 3.

5 http://www.depkes.go.id/downloads/SKN\% 20final.pdf, Diakses, tanggal 11 Juli 2020.

6 Rahmi Yuningsih, "Pengobatan Tradisional di Unit Pelayanan Kesehatan", Info Singkat Kesejahteraan Sosial, Vol. IV, No. 05/I/P3DI/maret 2012, Hlm. 1.

7 Ibid. ditambah dengan rumitnya pelayanan pada pengobatan konvesional dan cenderung mahal. Di antara pengobatan alternatif untuk penyembuhan penyakit adalah bekam (hijamah). Bekam merupakan salah satu metode penyembuhan alternatif yang terkategori sebagai thibbun nabawi atau metodologi pengobatan Nabi. Istilah thibbun nabawi ini dimunculkan oleh para dokter muslim sekitar abad 13 untuk memudahkan klasifikasi kedokteran. Salah satu maksudnya adalah untuk memudahkan dalam membedakan dengan pengobatan yang bertentangan atau tidak sesuai dengan prinsip Islam. ${ }^{8}$

Bekam atau hijamah merupakan suatu metode pengobatan yang sudah dikenal sejak jaman dahulu. Berawal dari kerajaan Sumeria, kemudian terus berkembang sampai Babilonia, Mesir, Saba' dan Persia. Selanjutnya bekam juga digunakan oleh umat Islam, kemudian berkembang juga pada jaman Cina kuno dan di Eropa pada kurun waktu abad ke-18 atau abad ke-13 Hijriyah. ${ }^{9}$

Berdasarkan kondisi tersebut perlu adanya undang-undang yang mengatur perlindungan konsumen, undang-undang yang mengatur perlindungan konsumen adalah Undang-undang No 8 Tahun 1999 tentang Perlindungan Konsumen. ${ }^{10}$

Kurangnya pengetahuan dan juga pemahaman yang menimbulkan konsumen menjadi suatu obyek bisnis untuk mencapai keuntungan yang sebesarbesarnya oleh pelaku usaha. Salah satu bagian perlindungan terhadap konsumen dari perilaku pelaku usaha yang menjadikannya hanya sebagai obyek bisnis,

8 Sunardi, Pengobatan Tradisional sebagai Pengobatan Alternatif, Solo: AlQowwam, 2008, Hlm. 75.

9 Kasmui, Bekam Pengobatan Menurut Sunnah Nabi, Semarang: Komunitas Thibbun Nabawi "ISYFI", 2010, HIm. 10.

10 Martin Roestamy dan Edy Supaino, Kepastian Hukum tentang Penggunaan Label Halal Guna Memberikan Perlindungan Kepada Konsumen Muslim, Jurnal Living Law, Volume 9 Nomor 1, Januari 2017, HIm. 49. 
sehingga dapat mendatangkan kerugian bagi konsumen. ${ }^{11}$

Perlindungan konsumen sebagaimana dimaksud dalam Undang-undang No 8 Tahun 1999 tentang Perlindungan Konsumen adalah segala upaya yang menjamin adanya kepastian hukum yang memberikan perlindungan kepada konsumen melalui asas keseimbangan, yang berarti perlindungan konsumen tersebut tidak hanya diberikan kepada konsumen tetapi juga kepada pelaku usaha yang jujur, beritikad baik, dan bertanggung jawab. ${ }^{12}$

Pengertian konsumen saat ini tidak lagi identik dengan pengertian masyarakat yang menggunakan produksi dari hasil industri dan perdagangan tetapi juga meliputi masyarakat pemanfaat jasa kesehatan. Pemanfaat jasa kesehatan di sini tidak hanya berfokus pada pengobatan konvensional, tetapi juga pada pengobatan tradisional. Sementara itu, dalam Undangundang Perlindungan Konsumen tersebut perlindungan konsumen ini masih merujuk pada perlindungan terhadap konsumen pengguna barang dan jasa pada bidang industri. Pemanfaat jasa pengobatan tradisional ini masih belum memiliki perlindungan hukum terhadap hak-hak sebagai konsumen. Pengobatan tradisional juga tidak mempunyai standar pengobatan untuk dijadikan acuan, seperti halnya standar pengobatan yang dimiliki oleh pengobatan konvensional. ${ }^{13}$

Berdasarkan uraian latar belakang masalah tersebut di atas, maka peneliti dalam penelitian ini mengambil judul

11 Muhammad Taufiq dan Herlin Setiani, Perlindungan Konsumen Atas Barang Yang Tidak Sesuai Dengan Perjanjian Dalam Perdagangan Elektronik Dikaitkan Dengan Undang-undang Informasi dan Transaksi Elektronik, Jurnal Living Law, Volume 10 Nomor 2, Oktober 2018, Hlm. 115.

12 Martin Roestamy dan Yose Priyono, Perlindungan Konsumen Dalam Klaim Asuransi Barang Pada Pembiayaan Kendaraan Bermotor Dikaitkan dengan Perjanjian Model Baku, Jurnal Living Law,Volume 7Nomor 2, Oktober 2015, Hlm. 225.

13 Rahmi Yuningsih, Op.Cit, Hlm. 1. tentang: "Perlindungan Hukum Terhadap Konsumen dari Pengobatan Tradisional Dengan Metode Pengobatan Bekam di Wilayah Bogor".

Berdasarkan latar belakang masalah yang telah diuraikan di atas, peneliti mengidentifikasi masalah sebagai berikut:

1. Bagaimana perlindungan hukum terhadap konsumen dari pengobatan tradisional dengan metode pengobatan bekam di Kabupaten dan Kota Bogor?

2. Bagaimana tanggung jawab pelaku usaha pengobatan tradisional dengan metode pengobatan bekam di Kabupaten dan Kota Bogor terhadap konsumen yang dirugikan?

\section{METODE PENELITIAN}

Metode penelitian yang digunakan dalam penelitian ini adalah pendekatan yuridis normatif, yaitu hukum dikonsepsikan sebagai norma, kaidah, asas atau dogma-dogma/yurisprudensi dan pendekatan yuridis empiris yaitu hukum sebagai gejala masyarakat, sebagai institusi sosial atau perilaku yang mempola.

\section{PEMBAHASAN}

\section{A. PERLINDUNGAN HUKUM TERHADAP KONSUMEN DARI PENGOBATAN TRADISIONAL DENGAN METODE PENGOBATAN BEKAM DI KABUPATEN DAN KOTA BOGOR}

Perlindungan hukum adalah suatu perlindungan yang diberikan tehadap subyek hukum dalam bentuk perangkat hukum baik yang bersifat preventif maupun yang bersifat represif, baik yang tertulis maupun tidak tertulis. Dengan kata lain perlindungan hukum sebagai suatu gambaran dari fungsi hukum, yaitu konsep di mana hukum dapat memberikan suatu keadilan, ketertiban, kepastian, kemanfaatan, kedamaian, ketentraman 
bagi segala kepentingan manusia yang ada di dalam masyarakat. ${ }^{14}$

Praktik-praktik pelayanan kesehatan tradisional kian berkembang di Indonesia, khususnya di Wilayah Kabupaten dan Kota Bogor. Masyarakat tidak ragu ataupun malu mendatangi tempat pengobatan tradisional dengan metode pengobatan bekam, baik hanya untuk berkonsultasi atau berobat. Pelayanan kesehatan tradisional masuk dalam ruang lingkup hukum perlindungan konsumen didasarkan pada pemikiran bahwa dalam menjalankan kegiatannya yaitu memberikan pelayanan kesehatan, pengobat tradisional dengan metode pengobatan bekam menetapkan tarif yang harus dikeluarkan oleh setiap orang yang berobat sehingga pelayanan kesehatan tradisional ini dapat dikatakan sebagai suatu bisnis.

Dalam suatu kegiatan usaha yang bertujuan untuk mendapatkan keuntungan ekonomi, pengobat tradisional dengan metode pengobatan bekam bertindak sebagai pelaku usaha dan pemanfaat jasa pelayanan kesehatan tradisional adalah konsumen. Sebagai konsumen, pemanfaat jasa pelayanan kesehatan tradisional memiliki hak-hak yang harus dipenuhi dalam hal pelayanan di bidang kesehatan.

Perlindungan hukum bagi konsumen timbul sebagai akibat dari adanya suatu hubungan hukum antara konsumen dengan pelaku usaha, di mana hubungan tersebut dapat menyebabkan suatu sengketa. Dalam hubungan hukum antara konsumen dengan pelaku usaha terdapat tiga fase yang menyebabkan terjadinya suatu sengketa, yaitu:

1) Fase Pra Transaksi, pada fase ini konsumen mengumpulkan informasi terhadap produk yang akan dikonsumsinya. Sumber informasi

14 Rahayu, Pengangkutan Orang (Studi tentang Perlindungan Hukum Terhadap Barang Bawaan Penumpang di PO. Rosalia Indah), Fakultas Hukum Universitas Muhammadiyah Surakarta, 2009, Hlm. 6. tersebut dapat berasal dari iklan, brosur, leaflet, dan lain-lain. Merupakan media dan sarana pelaku usaha untuk mengkomunikasikan produk-produk barang dan/atau jasa yang dibuat atau dipasarkan kepada konsumen. ${ }^{15}$ Sengketa dalam fase ini terjadi apabila konsumen (pemanfaat jasa pelayanan kesehatan tradisional dengan metode pengobatan bekam) meragukan kebenaran atas iklan yang dikeluarkan oleh pelaku usaha (pengobat tradisonal dengan metode pengobatan bekam) di media-media atau dengan kata lain konsumen merasa pelaku usaha tidak memberikan informasi yang jujur, benar, dan dapat dipertanggungjawabkan.

2) Fase Transaksi. Setelah konsumen mendapat informasi yang cukup maka dilanjutkan untuk membeli atau mengkonsumsi terhadap produk barang dan/atau jasa. Suatu perbuatan transaksi tidak akan terjadi begitu saja tanpa didahului dengan pengetahuan konsumen mengenai ikhwal dari suatu produk barang dan/atau jasa yang akan dibelinya tersebut dengan berbagai media informasi. ${ }^{16}$ Sengketa konsumen pada fase ini dapat terjadi apabila yang diinformasikan pelaku usaha (pengobat tradisional dengan metode pengobatan bekam) menyesatkan atau tidak benar, sehingga konsumen (pemanfaat jasa pelayanan kesehatan tradisional dengan metode pengobatan bekam) merasa dibohongi/ditipu.

3) Fase Purna Transaksi. Pada fase ini kemungkinan timbulnya sengketa adalah sangat besar. Pada fase inilah konsumen dapat menjadikan ajang untuk menguji bagaimana pelayanan purna jual beli para pelaku usaha atas kebenaran apa yang diklaim dalam iklan atau pada produknya, janj-janji

15 YLKI, Lika-Liku Perjalanan UUPK, Cet. 1, Jakarta: YLKI, 2001, HIm. 85.

16 Ibid., Hlm. 85-86. 
atau pernyataan tentang berbagai kegunaan, kemampuan, keunggulan atau kelebihan produk. Sejauh mana semua yang sudah diperjanjikan di dalam kontrak perjanjian dapat terealisasi. ${ }^{17}$

Berdasarkan Pasal 45 ayat (1) UUPK di atas disebutkan bahwa konsumen dapat menggugat pelaku usaha melalui lembaga yang bertugas menyelesaikan sengketa antara konsumen dengan pelaku usaha atau melalui peradilan umum. Penyelesaian sengketa melalui pengadilan dirasakan tidak dapat menyelesaikan permasalahan. Penyelesaian sengketa diharapkan sedapat mungkin tidak merusak hubungan antara pelaku usaha dengan konsumen.

Di samping itu, secara umum dapat dikemukakan berbagai kritikan terhadap penyelesaian sengketa malalui pengadilan, yaitu:

1) Penyelesaian sengketa melalui pengadilan sangat lambat.

2) Biaya perkara yang mahal.

3) Pengadilan pada umumnya tidak responsif.

4) Putusan pengadilan tidak menyelesaikan masalah.

5) Kemampuan para hakim yang bersifat generalis. ${ }^{18}$

Berdasarkan Pasal 49 UUPK, pemerintah membentuk suatu lembaga yang bertugas dalam melakukan penyelesaian sengketa konsumen di luar pengadilan, yaitu Badan Penyelesaian Sengketa Konsumen (BPSK). Selain BPSK, seiring dengan perkembangan hukum perlindungan konsumen di Indonesia muncul suatu lembaga yang juga mencurahkan perhatiannya pada perlindungan konsumen, yaitu Yayasan Lembaga Konsumen.

1. Badan Penyelesaian Sengketa Konsumen (BPSK)

Menurut Ketua BPSK Kabupaten Bogor, pelayanan kesehatan tradisional dengan metode pengobatan bekam dalam Undang-undang Perlindungan

17 Ibid., Hlm. 86.

${ }^{18}$ Ahmadi Miru, Op.Cit, Hlm. 155-157.
Konsumen termasuk dalam fungsi pembinaan dan pengawasan pemerintah. Hal ini sesuai dengan Pasal 29 dan 30 UUPK. Fungsi pembinaan dan pengawasan dilakukan oleh pemerintah, masyarakat, dan lembaga perlindungan konsumen swadaya masyarakat. ${ }^{19}$

Pelayanan kesehatan tradisional dengan metode pengobatan bekam dapat dikatakan sebagai suatu kegiatan bisnis yang bertujuan untuk mendatangkan manfaat ekonomi bagi pelaku usaha dan manfaat kesehatan bagi konsumen selaku pengguna jasa pelayanan kesehatan tradisional dengan metode pengobatan bekam. Konsumen sebagai pemanfaat jasa pelayanan kesehatan tradisional dengan metode pengobatan bekam berhak untuk mendapatkan pelayanan terbaik dari pelaku usaha pengobatan tradisional dengan metode pengobatan bekam sesuai dengan peraturan perundang-undangan yang berlaku. Jika konsumen mengalami kerugian, dapat melakukan pengaduan kepada BPSK. Namun, kerugian yang bisa diproses lebih lanjut oleh BPSK hanya kerugian materil. Jika konsumen pemanfaat jasa pelayanan kesehatan tradisional dengan metode pengobatan bekam ingin menuntut hak immaterialnya, sebaiknya langsung diajukan kepada pelayanan kesehatan tradisional dengan metode pengobatan bekam yang bersangkutan karena itu merupakan hak konsumen yang telah diatur dalam peraturan perundangundangan. ${ }^{20}$

Berkaitan dengan pelayanan kesehatan tradisional dengan metode pengobatan bekam, menurut Ketua BPSK, sejauh ini belum ada pengaduan dari masyarakat yang merasa dirugikan oleh pelaku usaha pelayanan kesehatan tradisional dengan metode pengobatan bekam.

19 Hasil wawancara dengan Ketua BPSK Kabupaten Bogor, Pada tanggal 16 Juli 2020.

20 Kurniasari, Op.Cit., Hlm. 77. 
Padahal dalam kegiatan pelayanan kesehatan tradisional dengan metode pengobatan bekam tidak menutup kemungkinan adanya permasalahan antara pelaku usaha pelayanan kesehatan tradisional dengan metode pengobatan bekam dengan konsumen sebagai pemanfaat jasa pelayanan kesehatan tradisional dengan metode pengobatan bekam. Oleh karena itu, BPSK menghimbau masyarakat khususnya konsumen pelayanan kesehatan tradisional dengan metode pengobatan bekam, jika mengalami suatu kerugian maka segera melakukan pengaduan kepada lembaga perlindungan konsumen atau kepada pihak yang berwenang agar kerugian tersebut dapat diproses lebih lanjut.

2. Yayasan Lembaga Konsumen (YLK)

Sebagai salah satu lembaga konsumen swadaya masyarakat, YLK dalam memberikan perlindungan kepada masyarakat memiliki tugas yang diantaranya yaitu mengingatkan kesadaran atas hak dan kewajiban dan kehati-hatian konsumen.

Sama seperti halnya di BPSK, menurut Ketua YLK, untuk saat ini belum ada pelaporan pengaduan dari konsumen pemanfaat jasa pelayanan kesehatan tradisional dengan metode pengobatan bekam. Tidak adanya pengaduan dari konsumen yang merasa dirugikan bukan berarti tidak ada permasalahan yang terjadi dalam kegiatan usaha pelayanan kesehatan tradisional dengan metode pengobatan bekam. Tidak adanya pengaduan dari konsumen mungkin disebabkan karena tidak mengetahui adanya lembaga perlindungan konsumen, tidak mengetahui mekanisme pengaduannya, atau merasa tidak perlu diadukan karena menganggap permasalahnnya tidak terlalu penting.

\section{B. TANGGUNG JAWAB PELAKU USAHA PENGOBATAN BEKAM TERHADAP KONSUMEN YANG DIRUGIKAN}

Undang-Undang tentang Perlindungan Konsumen telah mengatur perlindungan terhadap konsumen dalam lingkup hukum perdata dan hukum pidana terkait tanggung jawab pelaku usaha. Hal ini ditujukan untuk meningkatkan posisi konsumen dalam bertransaksi dengan pelaku usaha.

1. Pertanggungjawaban Pelaku Usaha Secara Perdata

Secara umum, tuntutan ganti kerugian atas kerugian yang dialami oleh konsumen sebagai akibat penggunaan produk, baik yang berupa kerugian materi, fisik maupun jiwa, dapat didasarkan pada beberapa ketentuan yang telah disebutkan, yang secara garis besarnya hanya ada dua kategori, yaitu tuntutan ganti kerugian berdasarkan wanprestasi dan tuntutan ganti kerugian berdasarkan perbuatan melanggar hukum. ${ }^{21}$ Ini merupakan bentuk pertanggungjawaban yang dapat dituntut pada seorang pelaku usaha secara perdata apabila terbukti melakukan kerugian pada konsumen.

a. Tuntutan Ganti Kerugian Berdasarkan Wanprestasi

Ganti kerugian yang diperoleh karena adanya wanprestasi merupakan akibat dari tidak terpenuhinya kewajiban utama atau kewajiban tambahan yang berupa kewajiban atas prestasi utama atau kewajiban jaminan/garansi dalam perjanjian. ${ }^{22}$ Pengertian dalam pasal di atas menyatakan bahwa seseorang dapat dikatakan telah melakukan wanprestasi apabila didahului dengan perjanjian kepada seseorang, namun ia tidak

21 Ahmadi Miru dan Sutarman Yodo, Op.Cit, Hlm. 127.

22 Ibid, Hlm. 128. 
memenuhi prestasi seperti yang telah dijanjikannya karena lalai. Jadi, untuk menentukan kapan seseorang telah melalaikan kewajibannya dapat dilihat dari isi perjanjian.

Apabila terjadi wanprestasi yang dilakukan oleh pengobat tradisional dengan metode pengobatan bekam, maka pertanggungjawabannya ada di pihak pengobat tradisional dengan metode pengobatan bekam itu sendiri. Untuk mengajukan gugatan dengan dasar wanprestasi itu, korban (konsumen pemanfaat jasa pengobatan bekam) harus membuktikan bahwa memang benar telah terjadi pe rikatan yang lahir dari perjanjian antara dirinya dengan pengobat tradisional dengan metode pengobatan bekam.

b. Tuntutan Ganti Kerugian Berdasarkan Perbuatan Melawan Hukum

Unsur-unsur yang harus dipenuhi untuk dapat menuntut ganti kerugian berdasarkan perbuatan melawan hukum antara lain:

i. Perbuatan Itu Harus Melawan Hukum

Perbuatan melanggar hukum tidak lagi hanya sekedar melanggar undang-undang, melainkan perbuatan melanggar hukum tersebut dapat berupa:

a. Melanggar hak orang lain;

b. Bertentangan dengan kewajiban hukum si pembuat;

c. Berlawanan dengan kesusilaan baik;

d. Berlawanan dengan sikap hatihati yang seharusnya diindahkan dalam pergaulan masyarakat terhadap diri atau benda orang lain. ${ }^{23}$

ii. Ada Kerugian

Bloembergen menyatakan bahwa: "kalau kita bicara tentang

23 Ibid, Hlm. 130. kerugian maka dapat dipikirkan suatu pengertian yang konkrit dan subyektif, yaitu kerugian nyata yang diderita oleh orang yang dirugikan, di mana diperhitungkan situasi yang konkrit dengan keadaan subyektif dari yang bersangkutan. Selain itu kita juga dapat memikirkan secara obyektif, di mana kita melepaskan diri seluruhnya atau sebagian dari keadaan konkrit dari orang yang dirugikan dan menuju ke arah yang normal."24

iii. Ada Hubungan Sebab Akibat (Kausal)

Ajaran kausalitas sangat penting untuk meneliti adanya hubungan kausal antara perbuatan melawan hukum dan kerugian yang ditimbulkan, sehingga pelaku dapat dimintai pertanggungjawaban.

Teori kausalitas yang pertama adalah ajaran Von Buri, yaitu Teori Conditio Sine Qua Non yang berarti syarat mutlak, teori ini melihat bahwa tiap-tiap masalah yang merupakan syarat untuk timbulnya suatu akibat adalah menjadi sebab dari suatu akibat. Ajaran ini disebut juga Equivalente Theorie. Ajaran ini terlalu luas sehingga tidak dipergunakan dalam hukum perdata maupun pidana. ${ }^{25}$

Oleh karena itu, diadakan pembatasan dengan menerapkan Adequate

(Adequate veroorzaking) dari Von Kries. Teori ini menyatakan bahwa perbuatan yang harus dianggap sebagai sebab dari akibat yang timbul adalah perbuatan yang seimbang dengan akibat.

iv. Ada Kesalahan (Schuld)

24 Ibid, Hlm. 134.

25 M.A. Moegni Djojodihardjo, Perbuatan Melawan Hukum, Jakarta: Pradnya Paramitha, 1979, Hlm. 90. 
Berdasarkan Pasal 1365 KUHPedata, salah satu syarat untuk membebani tergugat dengan tanggung gugat berdasarkan perbuatan melanggar hukum adalah adanya kesalahan. Kesalahan ini memiliki tiga unsur, yaitu:

a) Perbuatan yang dilakukan dapat disesalkan;

b) Perbuatan tersebut dapat diduga akibatnya;

i. Dalam arti obyektif: sebagai manusia normal dapat menduga akibatnya:

ii. Dalam arti subyektif: sebagai seorang ahli dapat menduga akibatnya;

c) Dapat di pertanggungjawabkan: debitur dalam keadaan cakap. ${ }^{26}$

Berdasarkan Pasal 1365 KUHPerdata, pengobat tradisional dengan metode pengobatan tradisional bekam yang melakukan tindakan pengobatan dapat digugat untuk dimintai pertanggungjawabannya dengan membayar ganti rugi atas perbuatan melawan hukum yang mengakibatkan kerugian kepada korbannya (konsumen pemanfaat jasa pelayanan kesehatan tradisional dengan metode pengobatan tradisional bekam). Dengan catatan bahwa unsur-unsur perbuatan melawan hukum dari pengobat tradisional dengan metode pengobatan tradisional bekam di sini harus tepenuhi dan dapat dibuktikan.

Dalam lingkup UUPK, maka pelaku usaha dalam hal ini adalah tenaga pengobat tradisional dengan metode pengobatan tradisional bekam yang

\footnotetext{
${ }^{26}$ Ahmadi Miru, Op.Cit, Hlm. 87.
}

bertanggung jawab memberikan ganti kerugian atas kerugian konsumen akibat mengonsumsi jasa pengobatan dengan metode pengobatan tradisional bekam. Dalam hal tidak terpenuhinya perjanjian wanprestasi atau perbuatan melawan hukum, maka dapat dituntut dengan ganti rugi. Penetapan besarnya ganti rugi bukan merupakan sesuatu yang mudah dapat dipastikan, terutama dalam bidang jasa pelayanan kesehatan.

Sebagaimana telah dijelaskan pada bagian sebelumnya, maka untuk menetapkan kerugian karena telah terjadinya suatu wanprestasi dan perbuatan melawan hukum dalam suatu transaksi pengobatan tradisional dengan metode pengobatan tradisional bekam, UUPK telah mengatur tentang bentuk ganti kerugian. Bentuk ganti kerugian berdasarkan UUPK dapat berupa pengembalian uang muka atau penggantian barang dan atau jasa yang sejenis atau setara nilainya dan perawatan kesehatan dan atau pemberian santunan yang sesuai dengan ketentuan peraturan yang berlaku.

Pada umumnya ganti kerugian yang diberikan kepada pihak yang menderita kerugian adalah dalam bentuk uang. Besarnya biaya atau uang yang dituntut dapat ditetapkan berdasarkan karakteristik peraturan perundang-undangan. Undang-undang dapat menentukan jumlah maksimum biaya yang diberikan atau berdasarkan pertimbangan putusan hakim dengan melihat dan mencermati kondisi kerugian yang timbul karena kesalahan atau kelalaian salah satu pihak.

2. Pertanggungjawaban Pelaku Usaha Secara Pidana

Undang-Undang Nomor 8 Tahun 1999 tentang Perlindungan Konsumen cukup banyak mengandung ketentuanketentuan pidana, termasuk di dalamnya diatur mengenai pertanggungjawaban pelaku usaha 
secara pidana. Hal ini dapat dilihat dalam Pasal 61 UUPK, bahwa tuntutan pidana dapat dilakukan terhadap pelaku usaha dan/atau pengurusnya.

Dengan ketentuan ini berarti badan usaha (badan hukum atau bukan badan hukum, perusahaan swasta atau publik, koperasi dan sebagainya) dapat diajukan sebagai terdakwa dalam suatu perkara pidana, di samping mereka yang bekerja sebagai pengurusnya. ${ }^{27}$ Jadi, pertanggungjawaban pidana dapat dilakukan terhadap pelaku usaha dan/atau pengurusnya apabila dapat dibuktikan unsur-unsur kesalahannya.

Ancaman pidana terhadap pelaku usaha atau pengurusnya itu dijelaskan pada Pasal 62 ayat (1), antara lain pidana penjara maksimal 5 (lima) tahun atau denda minimum Rp. 2.000.000.000,- (dua milyar rupiah), apabila melanggar ketentuan yang termuat dalam Pasal 8, 9, 10, 13, 15, 17 ayat (1) huruf a, b, c, d, e dan ayat (2), dan Pasal 18. Begitu pula dalam Pasal 62 ayat (2) menetapkan bahwa pelanggaran atas Pasal 11, 12, 13 ayat (1), 14, 16, dan Pasal 17 ayat (1) huruf d dan $f$, diancam dengan pidana penjara maksimum 2 (dua) tahun penjara atau denda maksimum Rp. 500.000.000,- (lima ratus juta rupiah). Sedangkan terhadap pelanggaran yang dilakukan pelaku usaha dan/atau pengurus yang mengakibatkan konsumen luka berat, sakit berat, cacat tetap, atau meninggal maka diberlakukan ketentuan pidana yang diatur dalam Pasal 63 ayat (3).

Dalam ketiga ayat tersebut di atas terlihat bahwa ancaman hukuman pidana penjara atau denda dapat dijatuhkan pada setiap pelaku usaha yang melakukan kesalahan. Ancaman pidana penjara dan denda merupakan bentuk pertanggungjawaban yang harus dilakukan oleh setiap pelaku

\footnotetext{
${ }^{27}$ Az Nasution, Op.Cit, Hlm. 221.
}

usaha yang terbukti melakukan pelanggaran.

Pelaku usaha atau pengurusnya masih dapat dijatuhi hukuman tambahan atas tindak pidana sebagaimana yang telah disebutkan di atas berdasarkan Pasal 63 UUPK, yang terdiri dari:

a) Perampasan barang tertentu.

b) Pengumuman keputusan hakim.

c) Pembayaran ganti rugi.

d) Perintah penghentian kegiatan tertentu yang menyebabkan timbulnya kerugian konsumen.

e) Kewajiban penarikan barang dari peredaran.

f) Pencabutan izin usaha.

Pertanggungjawaban pelaku usaha secara pidana juga dijelaskan pada Undang-undang Nomor 36 Tahun 2009 tentang Kesehatan, yaitu pertanggungjawaban pelaku usaha pada bidang pelayanan kesehatan.

Dalam Pasal 191 Undang-undang Nomor 36 Tahun 2009 tentang Kesehatan menjelaskan bahwa setiap orang yang tanpa izin melakukan praktik pelayanan kesehatan tradisional dengan metode pengobatan tradisional bekam yang menggunakan alat dan teknologi sebagaimana dimaksud dalam Pasal 60 ayat (1) (alat dan teknologi yang digunakan harus mendapat izin dari lembaga kesehatan yang berwenang) sehingga mengakibatan kerugian harta benda, luka berat atau kematian dipidana dengan pidana penjara paling lama 1 (satu) tahun dan denda paling banyak Rp. 100.000.000,- (seratus juta rupiah). Menurut ketentuan pidana dalam UUPK dan Undang-undang Kesehatan, pengobat tradisional dengan metode pengobatan tradisional bekam sebagai pelaku usaha dapat mempertanggungjawabkan tindakannya secara pidana apabila memang telah terbukti melakukan pelanggaran. Ancaman pidanannya dapat berupa, hukuman pidana penjara atau dengan membayar denda yang dijatuhkan sesuai dengan kesalahan yang 
dilakukan. Terhadap kegiatan pengobatan tradisional dengan metode pengobatan tradisional dapat dilakukan perintah penghentian apabila memang terbukti telah menimbulkan kerugian pada konsumen, serta izin usahanya dapat dicabut.

\section{KESIMPULAN}

Berdasarkan hasil penelitian dan pembahasan di atas, maka penulis dapat mengambil kesimpulan, sebagai berikut:

1. Perlindungan terhadap konsumen pengobatan tradisional dengan metode pengobatan bekam di Kabupaten Bogor dan Kota Bogor, dalam penyelesaian sengketa dapat dilakukan melalui mekanisme yang telah diatur dalam Undang-undang Perlindungan Konsumen, yakni melalui mekanisme penyelesaian sengketa di dalam pengadilan atau di luar pengadilan. Ini merupakan bentuk upaya hukum yang dapat dilakukan oleh konsumen pengobatan tradisional dengan metode pengobatan bekam yang merasa dirugikan, mereka dapat mengajukan gugatan ke pengadilan atau menyelesaikan sengketannya di luar pengadilan.

2. Tanggung jawab pelaku usaha pengobatan tradisional dengan metode pengobatan bekam di Kabupaten dan Kota Bogor terhadap konsumen yang dirugikan dapat mempertanggungjawabkan tindakannya secara perdata maupun pidana. Hal ini ditujukan untuk meningkatkan posisi tawar konsumen pengobatan tradisional dengan metode pengobatan bekam dalam bertransaksi dengan pelaku usaha pengobatan tradisional dengan metode pengobatan bekam, sehingga tidak diperlakukan sewenang-wenang karena telah ada undang-undang yang mengaturnya.

\section{SARAN}

1. Dilakukan pengawasan secara berkala dan berkelanjutan yang dilakukan oleh pemerintah pusat berkoordinasi dengan pemerintah daerah terhadap praktik pelayanan kesehatan tradisional dengan metode pengobatan tradisional bekam, terutama di daerah yang marak tempat pelayanan kesehatan tradisionalnya, seperti di Kabupaten Bogor dan Kota Bogor dan melakukan koordinasi antara pihak-pihak terkait yaitu Dinas Kesehatan Kabupaten Bogor, Dinas Kesehatan Kota Bogor, Puskesmas, Pelayanan Kesehatan Tradisional, dan Badan Penyelesaian Sengketa Konsumen (BPSK).

2. Dalam Undang-undang Perlindungan Konsumen dan Undang-undang Kesehatan perlu ditambahkan muatan yuridis yang mengatur mengenai pelayanan kesehatan tradisional dengan metode pengobatan tradisional bekam, hubungan antara pengobat tradisional dengan konsumen secara tegas.

\section{DAFTAR PUSTAKA}

A. Buku:

Ahmadi Miru dan Sakka Pati, Hukum Perikatan, Penjelasan Makna Pasal 1233 sampai 1456 BW., Jakarta: PT. RajaGrafindo Persada, 2008.

Anonim, Bekam Mujizat Nabi, Jakarta: Asosiasi Bekam Indonesia (ABI), 2011.

Ari Yunanto, Hukum Pidana Malpraktik Medik (Tinjauan dan Perspektif Medikolegal, Yogyakarta: Penerbit Andi, 2010. 
Cecep Triwibowo, Etika \& Hukum Kesehatan, Yogyakarta: Medical Book, 2014.

Kasmui, Bekam Pengobatan Menurut Sunnah Nabi, Semarang: Komunitas Thibbun Nabawi "ISYFI", 2010.

M.A. Moegni Djojodihardjo, Perbuatan Melawan Hukum, Jakarta: Pradnya Paramitha, 1979.

Rahayu, Pengangkutan Orang (Studi tentang Perlindungan Hukum Terhadap Barang Bawaan Penumpang di PO. Rosalia Indah), Fakultas Hukum Universitas Muhammadiyah Surakarta, 2009.

Subekti, Hukum Perjanjian, Cet. 19, Jakarta: PT Intermasa, 2002.

Sunardi, Pengobatan Tradisional sebagai Pengobatan Alternatif, Solo: AlQowwam, 2008.

Viki Pemuda Indra Sakti, Perlindungan Hukum Bagi Konsumen Pengobatan Tradisional di Indonesia (Studi Kasus: Pengobatan Tradisional Pembesaran Alat Vital Pria), Jakarta: Fakultas Hukum Universitas Indonesia, 2009.

YLKI, Lika-Liku Perjalanan UUPK, Cet. 1, Jakarta: YLKI, 2001.

B. Jurnal Hukum

Dian Kartika, dkk, Pelayanan Kesehatan Tradisional dan Perlindungan Hukum Bagi Pasien, SOEPRA dalam Jurnal Hukum Kesehatan, Semarang: Universitas Katolik Soegijapranata, Vol 2, No 1, Tahun 2016.

Endeh Suhartini, Martin Roestamy, Danang Wijayanto, Asas Keadilan Dalam Suplai Makan Tahanan Kepolisian dan Lembaga Pemasyarakatan Dihubungkan Dengan Undangundang Nomor 36 Tahun 2009, Jurnal Ilmiah Living Law, Volume 12 Nomor 1, Januari 2020.

Endeh Suhartini, Ujang Bahar, Dani Purwanto, Optimalisasi Perlindungan Hukum Tenaga Kerja Dalam Aspek Keselamatan Kerja Pada Proyek Konstruksi di Wilayah Bogor, Jurnal Ilmiah Living Law, Volume 12 Nomor 1, Januari 2020.

C. Peraturan Perundang-undangan

Undang-undang Dasar Negara Republik Indonesia Tahun 1945.

Kitab Undang-undang Hukum Perdata (KUHPerdata).

Undang-undang Nomor 8 Tahun 1999 tentang Perlindungan Konsumen.

Undang-undang Nomor 36 Tahun 2009 tentang Kesehatan.

Keputusan Menteri Kesehatan (Kepmenkes) No. 1076//MENKES/SK/VII/2003 tentang Penyelenggaraan Pengobatan Tradisional. 